\title{
EFFECTS OF ANDROGEN ON DNA SYNTHESIS IN IMMATURE RAT UTERI
}

\author{
Shinobu SAKAMOTO, Yoshie SUGIURA*, Vinci MIZUHIRA*, \\ Tohru KAWASAKI, Shuji SASSA, Aкiнiкo KUMAI \\ AND RYOHEI OKAMOTO
Departments of Endocrinology and Cell Biology*, Medical Research Institute, Tokyo Medical and Dental University, 1-5-45, I'ushima, Bunkyo-ku, Tokyo 113

Received for publication March 14, 1985 and in revised form April 8, 1985

\begin{abstract}
The effects of testosterone and $17 \beta$-estradiol on uterine thymidine kinase (TK) activity in immature rats were investigated. Injection of either compound alone resulted in a more than 30 -fold increase in $\mathrm{TK}$ activity $30 \mathrm{hr}$ later. Injection of the two compounds together resulted in an even greater increase in TK activity and in the activities of its isozymes separated by DEAE cellulose column chromatography. Autoradiographic examination showed that testosterone alone induced marked DNA synthesis in the endometrial stroma and myometrium, but not in the endometrial epithelium, and that its effect on DNA synthesis in all these tissues was enhanced by the additional injection of $17 \beta$-estradiol.
\end{abstract}

Estrogens have long been thought to be important in the etiology of endometrial cancer, but in subjects of advanced postmenopausal age the ovary no longer produces estrogens. Calanog (3) reported that the level of androstenedione and the rate of its conversion to estrone were higher in patients with endometrial cancer than in control postmenopausal subjects. Moreover, testosterone secretion from the ovary is also significantly increased in patients with endometrial cancer $(2,4)$. On the other hand, Judd $(8,9)$ reported that the levels of androstenedione, testosterone, estrone and estradiol in patients with endometrial cancer were similar to those in control postmenopausal subjects, and MacDonald (12) observed that obesity enhanced the conversion of androstenedione to estrone in postmenopausal women with or without endometrial cancer.

Thymidine kinase (TK; EC 2.7.1.21), which acts in the pyrimidine salvage pathway, catalyzes the phosphorylation of deoxythymidine and is involved in DNA replication. High TK activity has been found in proliferating tissues $(6,13,14,19)$. We previously found that progesterone inhibited uterine TK activity induced by estrogen in immature rats (16), but the effects of androgens on the endometrium or their role in endometrial cancer are still unclear. Therefore, in the present work, we examined the effects of androgen on TK activity and its isozymes and on $\left[{ }^{3} \mathrm{H}\right]$ thymidine incorporation into rat uteri. 


\section{MATERIALS AND METHODS}

\section{Animals and Chemicals}

Immature female Sprague-Dawley strain rats of 20 to 22 days old were used in studies on uterine TK activity after injection of $17 \beta$-estradiol $(1.0 \mu \mathrm{g} / 100 \mathrm{~g}$ body weight, Merck, Darmstadt, West Germany) and/or testosterone $(1.0 \mathrm{mg} / 100 \mathrm{~g}$ body weight, Merck) suspended in $0.9 \% \mathrm{NaCl}$ solution. Control animals were treated with $0.9 \% \mathrm{NaCl}$ solution in a similar manner. Groups of 10 rats were sacrificed by cervical dislocation, and their uteri were removed and stored at $-80^{\circ} \mathrm{C}$.

\section{Preparation of Enzyme Extract}

Uteri were pulverized with an autopulverizer (a gift from Professor E. V. Jensen, Ben May Laboratory for Cancer Research, University of Chicago, Ill.) under liquid nitrogen and then homogenized with 10 volumes of $50 \mathrm{mM}$ Tris- $\mathrm{HCl}$ buffer (pH 7.5)/1 mM EDTA $/ 5 \mathrm{mM}$ mercaptoethanol at $0^{\circ} \mathrm{C}$. The homogenate was centrifuged for $1 \mathrm{hr}$ at $4^{\circ} \mathrm{C}$ at $105,000 \times \mathrm{g}$ and the supernatant was used as a crude enzyme preparation.

\section{Assay of TK activity}

TK activity was determined by Taylor's method (19). The assay mixture $(200 \mu \mathrm{l})$, consisting of $5 \mathrm{mM} \mathrm{MgCl}_{2}, 10 \mathrm{mM}$ ATP, $2 \mu \mathrm{M}\left[6-\mathrm{H}^{3}\right]$-thymidine (28.5 Ci $/ \mathrm{mmol}$, NEN, Boston, Mass.), and $0.1 \mathrm{M}$ Tris- $\mathrm{HCl}$ buffer ( $\mathrm{pH} 7.5$ ), was incubated with the enzyme preparation at $30^{\circ} \mathrm{C}$ : for $15 \mathrm{~min}$, and then $100 \mu \mathrm{l}$ of the mixture was spotted onto $1.8 \mathrm{~cm}$ squared DEAE cellulose paper (Toyo Filter, Tokyo, Japan). The paper was washed successively with $1 \mathrm{mM}$ ammonium formate and methanol, and the radioactivity of the dried paper was counted in a liquid scintillation spectrometer. Values are means for duplicate assays. Protein concentration of the enzyme solution was estimated by the method of Lowry using bovine serum albumin as the reference standard.

\section{DEAE Cellulose Chromatography}

TK isozymes from immature rat uteri were separated by DEAE cellulose column chromatography as previously reported (16). For examination of changes in uterine TK isozymes induced $30 \mathrm{hr}$ after the injection of $17 \beta$-estradiol and/or testosterone, the crude uterine extract was fractionated with ammonium sulfate. Saturated ammonium sulfate $(\mathrm{pH} 7.5)$ was added to the crude extract to $50 \%$ saturation, and the mixture was stirred for $1 \mathrm{hr}$ and then centrifuged at $10,000 \times \mathrm{g}$ for $20 \mathrm{~min}$. The precipitate was dissolved in $5 \mathrm{mM}$ Tris- $\mathrm{HCl}$ buffer $(\mathrm{pH} \mathrm{7.5}) / 20 \%$ glycerol/1 $\mathrm{mM} \mathrm{MgCl}_{2}$, and dialyzed overnight against the same buffer. The dialysate was centrifuged at $10,000 \times \mathrm{g}$ for $30 \mathrm{~min}$, and the supernatant was loaded on a DEAE cellulose (DE-52, Whatman, Kent, U.K.) column $(1.5$ by $5.0 \mathrm{~cm}$ ) equilibrated with the same buffer. Material was eluted stepwise with $10 \mathrm{ml}$ volumes of the same buffer containing $0 \mathrm{M}, 0.1 \mathrm{M}, 0.2 \mathrm{M}, 0.3 \mathrm{M}$, and $0.4 \mathrm{M} \mathrm{NaCl}$ and fractions of $2.0 \mathrm{ml}$ were collected. In experiments on inhibition of uterine TK activity by nucleotides, deoxythymidine triphosphate (dTTP) and deoxycytidine triphosphate (dCTP) were added to the reaction mixture at final concentrations of $0.5,1.0$ and $5.0 \mathrm{mM}$. 


\section{Autoradiography of Rat Uteri}

$\left[{ }^{3} \mathrm{H}\right]$-Thymidine $(28.5 \mathrm{Ci} / \mathrm{mmol}, \mathrm{NEN}, 5 \mu \mathrm{Ci} / \mathrm{g}$ body weight $)$ was injected into the tail vein of immature rats $28 \mathrm{hr}$ after the injection of $0.9 \% \mathrm{NaCl}$ solution, $17 \beta$-estradiol and/or testosterone. The uterus was removed $2 \mathrm{hr}$ later, cut into small pieces and fixed in a $0.1 \mathrm{M}$ cacodylate buffer containing $2 \%$ paraformaldehyde and $1 \%$ glutaraldehyde $(\mathrm{pH} 7.2)$ at $4^{\circ} \mathrm{C}$ for $2 \mathrm{hr}$. The fixed specimen was soaked overnight in the same buffer containing $7 \%$ sucrose at $4^{\circ} \mathrm{C}$. Tissue blocks were dehydrated in a glycol methacrylate (GMA) (1) series and embedded in GMA. Tissue sections $0.8 \mu \mathrm{m}$ thick were covered with Kodak NTB-2 emulsion, exposed at $4^{\circ} \mathrm{C}$ for 1 week, developed with Dektol (Kodak) at $15^{\circ} \mathrm{C}$ for $4 \mathrm{~min}$, and stained with methylene blue and basic fuchsin.

\section{Statistical Analyses}

Student's t test was used and a $\mathrm{p}$ value of less than $5 \%$ was considered as significant.

\section{RESULTS}

Testosterone, with or without $17 \beta$-estradiol, induced marked and similar increases in uterine TK activity in immature rats $18 \mathrm{hr}$ after its injection. In both cases, the activity was maximal after $30 \mathrm{hr}$, and then gradually returned to the basal level after $72 \mathrm{hr}$. A similar time course of induction of TK activity by $17 \beta$-estradiol has been reported (16). As shown in Table 1 , the maximum enzyme activities induced by $17 \beta$-estradiol and testosterone were both $30-40$ times the basal activity. Administration of $17 \beta$-estradiol plus testosterone induced a significantly greater increase $(p<0.001)$ in the activity than that of either compound alone.

The TK isozymes from immature rat uteri were separated by DEAE cellulose column chromatography (Fig. 1). The activities eluted at $\mathrm{NaCl}$ concentrations of $0 \mathrm{M}, 0.1 \mathrm{M}$ and $0.2 \mathrm{M}$ were named peaks $\mathrm{A}, \mathrm{B}$, and $\mathrm{C}$. The elution profiles of activity from uteri treated with $17 \beta$-estradiol and testosterone were similar. Both compounds induced a marked increase in peak $\mathrm{A}$ activity, with slight increases in activities in peaks $B$ and $\mathrm{C}$, and simultaneous injection of both compounds together induced a greater increase in all those peaks than those with either compound

TABLE 1. Wet weight and thymidine kinase (TK) activity of immature rat uterus $30 \mathrm{hr}$ afler injection of $0.9^{\circ}{ }_{\circ} \mathrm{NaCl}$ solution as a control, $17 \beta$-estradiol $\left(E_{2} ; 1.0 \mu \mathrm{g} / 100 \mathrm{~g}\right.$ body weight), and/or testosterone $(T ; 1.0 \mathrm{mg} / 100 \mathrm{~g}$ body weight $)$

\begin{tabular}{lcc}
\hline & $\begin{array}{c}\text { Uterine wet weight } \\
(\mathrm{mg} / 100 \mathrm{~g} \text { body weight })\end{array}$ & $\begin{array}{c}\text { TK activity } \\
(\mathrm{pmol} / \mathrm{min} / \mathrm{mg} \text { protein })\end{array}$ \\
\hline Control & $69.8 \pm 3.2$ & $0.35 \pm 0.05(1)$ \\
$\mathrm{E}_{2}$ & $183.8 \pm 5.9$ & $13.80 \pm 0.82(2)$ \\
$\mathrm{T}$ & $174.7 \pm 9.3$ & $13.48 \pm 0.90(3)$ \\
$\mathrm{E}_{2}+\mathrm{T}$ & $204.1 \pm 6.6$ & $18.44 \pm 0.75(4)$
\end{tabular}

The enzymic activities were expressed in $\mathrm{pmol} / \mathrm{min} / \mathrm{mg}$ protein. Mean $\pm \mathrm{SE}(\mathrm{n}=10)$; (1) versus (2), (3) and (4), and (2) and (3) versus (4): statistically significant ( $p<$ 0.001 ). 


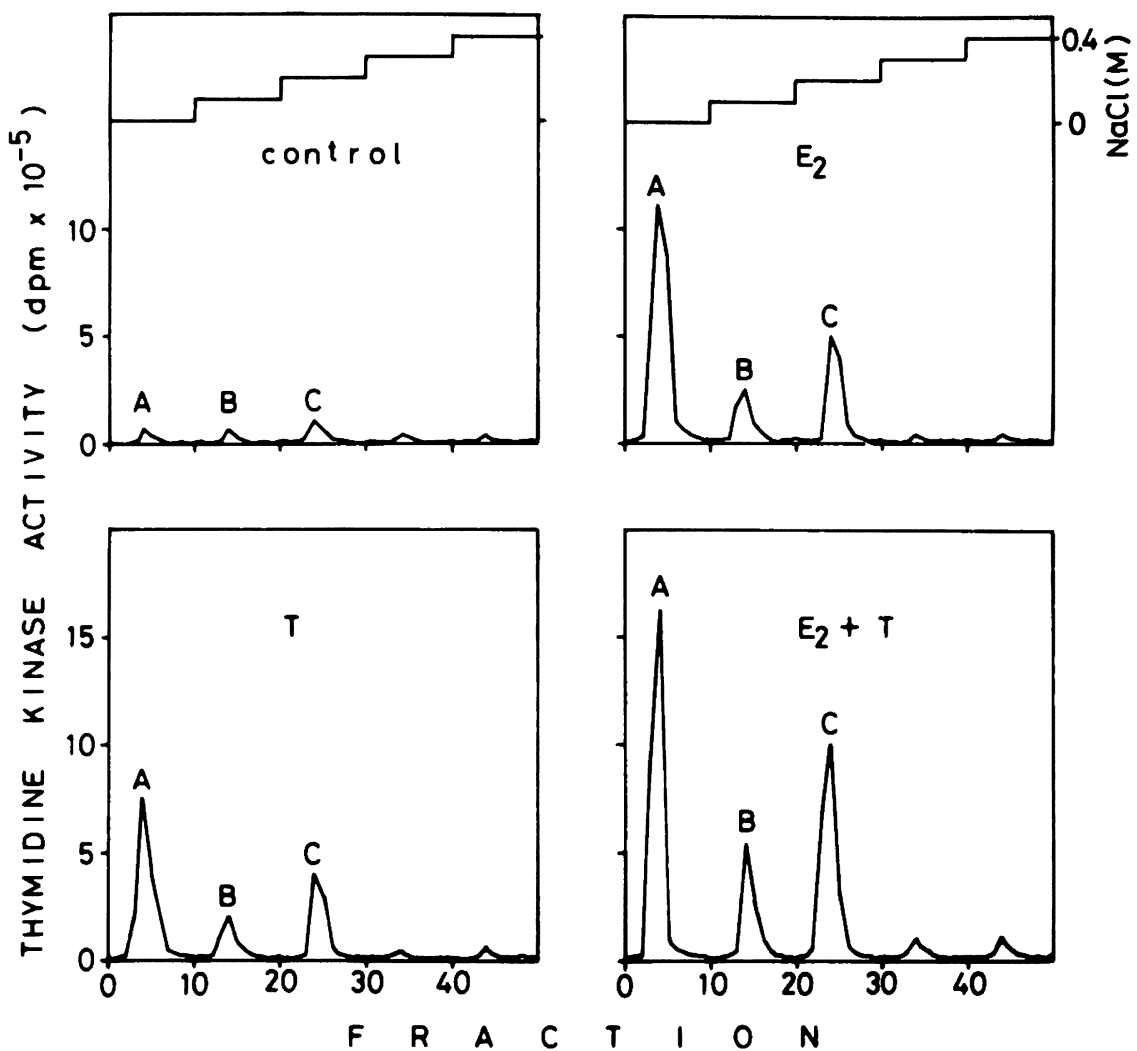

Fig. 1. The typical elution profiles of DEAE cellulose column chromatography of uterine thymidine kinase (TK) activity in every 10 immature rats treated with $17 \beta$-estradiol $\left(E_{2}\right)$ and/or testosterone (T). Uteri were separated $30 \mathrm{hr}$ after injection of $0.9 \% \mathrm{NaCl}$ solution as a control, $\mathrm{E}_{2}, \mathrm{~T}$ or $\mathrm{E}_{2}+\mathrm{T}$. Uterine TK activities eluted at $\mathrm{NaCl}$ concentration of $0.0 \mathrm{M}, 0.1 \mathrm{M}$ and $0.2 \mathrm{M}$ were defined as peaks $\mathbf{A}, \mathbf{B}$ and $\mathbf{C}$.

TABLE 2. Activities of uterine thymidine kinase isozymes separated by DEAE cellulose column chromatography

Fraction in DEAE cellulose column chromatography

Control

$17 \beta$-Estradiol

Testosterone

17 $\beta$-Estradiol plus Testosterone

Inhibition by dCTP
Thymidine kinase activity $\left(\mathrm{dpm} \times 10^{-5}\right)$

\begin{tabular}{ccc} 
Peak A ${ }^{\text {a) }}$ & Peak B & Peak C \\
\hline 1 & 1 & 2 \\
21 & 5 & 10 \\
14 & 4 & 7 \\
27 & 9 & 20 \\
$(-)^{\text {b) }}$ & $(+)$ & $(+)$
\end{tabular}

a) Activity of each thymidine kinase isozyme (Peaks A, B, and C) was estimated from chormatograms shown in Fig. 1.

b) Peak $A$ activity was not inhibited, and an increase in activity was observed, but the activities of peaks $B$ and $C$ were reduced by $1 \mathrm{mM}$ deoxycytidine triphosphate (dCTP). 
alone (Table 2).

Since a TK isozyme that is not affected by dCTP has been reported to be involved in DNA replication $(13,19)$, we examined the effects of nucleotides on the uterine TK isozymes. On treatment with $1 \mathrm{mM}$ dCTP, the peak A activity induced by $17 \beta$-estradiol or testosterone alone was not inhibited, and in fact showed an increase in activity, but the activities of peaks B and C were reduced (Table 2). Thus this peak A activity induced by $17 \beta$-estradiol or testosterone may correspond to that of the isozyme involved in DNA synthesis.

The effects of $17 \beta$-estradiol and/or testosterone on incorporation of $\left[{ }^{3} \mathrm{H}\right]-$ thymidine into uterine tissues were studied in immature rats by autoradiography. No grains were seen over uterine tissue on administration of $\left[{ }^{3} \mathrm{H}\right]$-thymidine to the control rats, indicating the absence of DNA synthesis (Fig. 2A). On the other hand, many grains were seen on the endometrial epithelium, stroma, and myometrium

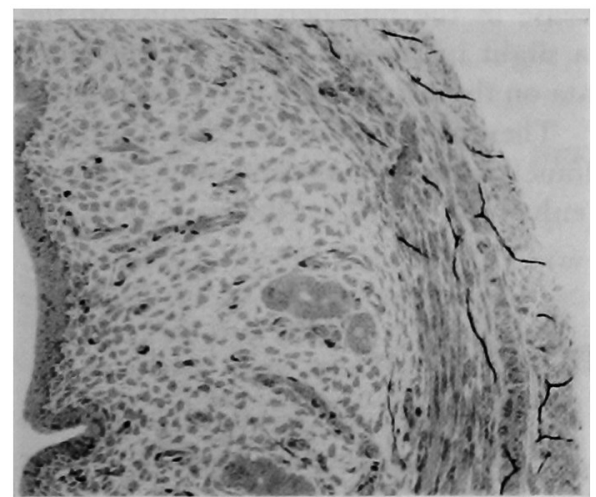

A

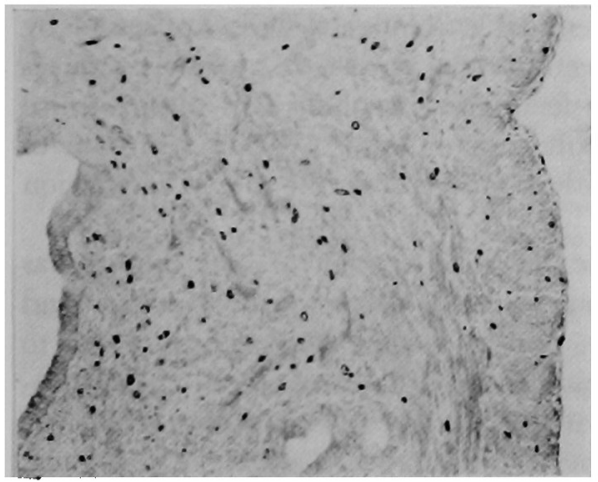

C

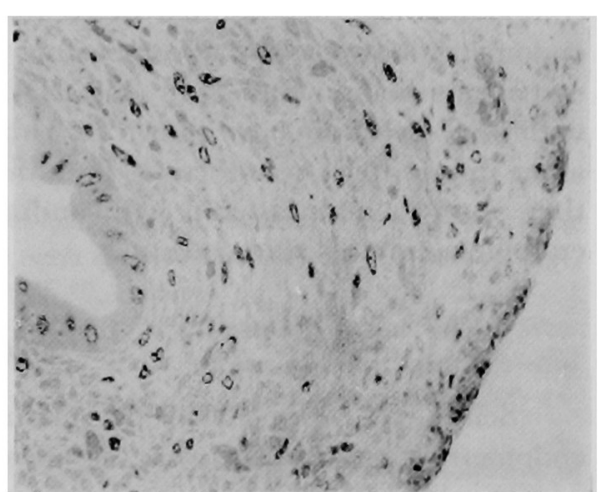

B

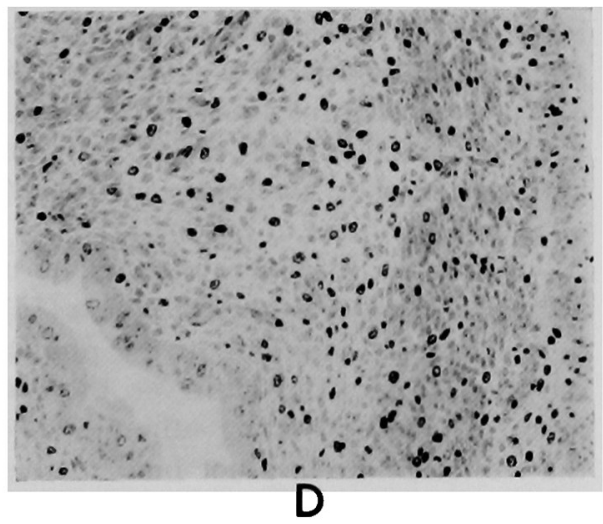

Figs. 2A-D. Autoradiograms of rat uterus $2 \mathrm{hr}$ after injection of $\left[{ }^{3} \mathrm{H}\right]$-thymidine. $\left[{ }^{3} \mathrm{H}\right]$-thymidine ( $5 \mu \mathrm{Ci} / \mathrm{g}$ body weight) was injected into the tail vein of immature rats $28 \mathrm{hr}$ after injection of $0.9^{\circ}$ ", $\mathrm{NaCl}$ solution as a control, $17 \beta$-estradiol $\left(\mathrm{E}_{2} ; 1.0 \mu \mathrm{g} / 100 \mathrm{~g}\right.$ body weight), and/or testosterone ( $\mathrm{T}$; $\left(1.0 \mathrm{mg} / 100 \mathrm{~g}\right.$ body weight). A. Uterus of control rat. B. Uterus of rat treated with $\mathrm{E}_{2}$ alone. C. Uterus of rat treated with $\mathrm{T}$ alone. D. Uterus of rat treated with $\mathrm{E}_{2}$ plus $\mathrm{T}$. (Original magnification $\times 200$ ) A few nuclei were stained deeply, but no grains were seen in control uterus. 
TABLE 3. Percentages of nuclei labelled with $\left[{ }^{3} H\right]$-thymidine

\begin{tabular}{lccc} 
& \multicolumn{2}{c}{ Endometrium } & \\
& Epithelium & Stroma & Myometrium \\
Control & 0 & 0 & 0 \\
$17 \beta$-Estradiol & $26.0 \pm 3.5$ & $22.6 \pm 5.1$ & $15.6 \pm 2.2$ \\
Testosterone & 0 & $22.7 \pm 4.8$ & $16.1 \pm 1.5$ \\
$17 \beta$-Estradiol + Testosterone & $28.0 \pm 3.7$ & $32.2 \pm 4.0$ & $32.7 \pm 5.2$ \\
mean \pm S.D. $(\mathbf{n}=5)$ & - & &
\end{tabular}

$30 \mathrm{hr}$ after administration of $17 \beta$-estradiol, indicating active DNA synthesis in these cells (Fig. 2B). Many grains were seen on the endometrial stroma and myometrium $30 \mathrm{hr}$ after administration of testosterone (Fig. 2C). Administration of both compounds together resulted in greater increase in the numbers of grains on the endometrial stroma and myometrium, and a slight increase in those on the endometrial epithelium after $30 \mathrm{hr}$ (Fig. 2D). Data on the percentages of nuclei labelled with $\left[{ }^{3} \mathrm{H}\right]$-thymidine are shown in Table 3 . These results indicate that androgen alone induced DNA synthesis in both the endometrial stroma and myometrium, and that estrogen administered with androgen enhanced DNA synthesis in both the endometrium and myometrium.

\section{DISCUSSION}

Scirpa (18) found that the plasma androstenedione levels in patients with endometrial hyperplasia were significantly higher than those of normal pre- or post-menopausal subjects, whereas their plasma estrone levels were similar to those of the normal subjects. On the other hand, Kaslaris and Jull (10) observed that the induction of uterine tumors in mice by chemical carcinogens was suppressed by androgen administration. This may have been because androgen probably reduces ovarian secretion of estrogen by a pituitary feedback mechanism in mature mice with a normal estrous cycle. In women after menopause, ovarian secretion of androgen in place of estrogen increases (8) with the increase in the rate of conversion of androstenedione to estrone (3).

Androgen is known to stimulate uterine cell proliferation $(7,11)$, and it has a specific receptor in the rat uterus (15), though a large dose of androgen can bind to the estrogen receptor in the uterus (17), and androgen may be converted to estrogen in vitro (3). However, there are reports that testosterone and $5 \alpha$-dihydrotestosterone have strong affinities for the uterine androgen receptor (15), and that testosterone does not bind to the estrogen receptor in vivo $(17,20)$. These reports suggest that the effect of testosterone on uterine TK activity is not related to the estrogen receptor, and that estrogen and androgen increase uterine TK activity independently. We found that estrogen and androgen both stimulated the endometrial stroma and myometrium, and that they had more effect in combination than singly on the activities of crude TK and the partially purified TK isozymes (Tables 1 and 2 ), and on $\left[{ }^{3} \mathrm{H}\right]$-thymidine incorporation into immature rat uteri (Fig. 2 and Table 3). Huggins (7) reported that estrogen and androgen have the 
same target cells in the vagina of rats, while Hager (5) demonstrated that in chick oviducts dexamethasone has a synergistic action with estrogen in induction of ovalbumin and conalbumin by binding to its receptor, which is distinct from the estrogen receptor.

In the present study, testosterone alone induced markedly DNA synthesis in the endometrial stroma and myometrium, but not the endometrial epithelium. Furthermore, 17 $\beta$-estradiol enhanced the effect of testosterone in all regions. These results suggest that endometrial carcinogenesis may be promoted under conditions of excessive stimulation by estrogens and androgens over a long period.

\section{ACKNOWLEDGEMENTS}

We thank Drs. N. Yamaka and K. Seki for biochemical and histological cooperation, and Misses $\mathrm{K}$. Kawasaki and A. Ishii for their excellent technical assistance.

\section{REFERENCES}

1. Bennet, H. S., Wyrick, A. D., Lee, S. W. and McNeil, J. H. Jr.: Science and art in preparing tissues embedded in plastic for light microscopy, with special reference to glycol methacrylate, glass knives and simple stains. Stain Technol. 51; 71-97, 1976.

2. Bremond, A. G., Claustrat, B., Rudigoz, R. G., Seffert, P. and Corniau, J.: Estradiol, androstenedione, testosterone, and dehydroepiandrosterone sulfate in the ovarian and peripheral blood of postmenopausal patients with and without endometrial cancer. Gynecol. Oncology 14; 119-124, 1982.

3. Calanog, A., Sall, S., Gordon, G. G. and Southren, A. L.: Androstenedione metabolism in patients with endometrial cancer. Am. J. Obstet. Gynecol. 129; 553-556, 1977.

4. Grattarola, R.: Increased androgenic activity in well-differentiated endometrial adenocarcinoma. Gvnecol. Oncology 14; 40-48, 1982.

5. Hager, L. J., Mcknight, G. S. and Palmiter, R. D.: Glucocorticoid induction of egg white mRNAs in chick oviduct. J. Biol. Chem. 255; 7796-7800, 1980.

6. Herzfeld, A. and Greengard, O.: Enzyme activities in human fetal and neoplastic tissues. Cancer 46; 2047-2054, 1980.

7. Huggins, C., Jensen, E. V. and Cleveland, A. S.: Chemical structure of steroids in relation to promotion of growth of the vagina and uterus of the hypophysectomized rat. J. Exp. Med. 100; 225-240, 1954.

8. Judd, H. L., Judd, G. E., Lucas, W. E. and Yen, S. S. C.: Endocrine function of the postmenopausal ovary. J. Clin. Endocrinol. Metab. 39; 1020-1024, 1974.

9. Judd, H. L., Davidson, B. J., Frumar, A. M., Shamonki, I. M., Lagasse, L. D. and Ballon, S. C.: Serum androgens and estrogens in postmenopausal women with and without endometrial cancer. Am. J. Obstet. Gynecol. 136; 859-871, 1980.

10. Kaslaris, E. and Jull, J. W.: The induction of tumors following the direct implantation of four chemical carcinogens into the uterus of mice and the effect of strain and hormones thereon. Brit. J. Cancer 16; 479-483, 1962.

11. Lerner, L. J., Hilf, R., Tuekheimer, A. R., Michel, I. and Engel, S. L.: Effects of hormone antagonists on morphological and biochemical changes induced by hormonal steroids in the immature rat uterus. Endocrinology 78; 111-124, 1966.

12. MacDonald, P. C., Edman, C. D., Hemsell, D. L., Porter, J. C. and Siiteri, P. K.: Effect of obesity on conversion of plasma androstenedione to estrone in postmenopausal women with and 
without endometrial cancer. Am. J. Obstet. Gynecol. 130;448-455, 1978.

13. Nawata, H. and Kamiya, T.: Two molecular forms of thymidine kinase in the cytosol of regenerating rat liver. J. Biochem. 78; 1215-1224, 1975.

14. Okuda, H., Arima, T., Hashimoto, T. and Fujii, S.: Multiple forms of deoxythymidine kinase in various tissues. Cancer Res. 32; 791-794, 1972.

15. Rochefort, H. and Lignon, F.: Differences between the estradiol and testosterone receptors in rat uterus. Eur. J. Biochem. 48; 503-512, 1974.

16. Sakamoto, S., Abe, A., Kudo, H., Yamada, N., Seki, K. and Okamoto, R.: Effects of estrogen and progesterone on thymidine kinase activity in immature rat uterus. Am. J. Obstet. Gynecol. 145; 711-715, 1983.

17. Schmidt, W. N., Sadler, M. A. and Katzenellenbogen, B. S.: Androgen-uterine interaction: nuclear translocation of the estrogen receptor and induction of the uterine-induced protein (IP) by high concentrations of androgens in vitro but not in vivo. Endocrinology 98; 702-716, 1976.

18. Scirpa, P., Mango, D., Battaglia, F., Scirpa, S. and Montemurro, A.: Plasma androstenedione and oestrone levels before and after the menopause. Maturitas 4; 33-42, 1982.

19. Taylor, A. T., Stafford, M. A. and Jones, O. W.: Properties of thymidine kinase partially purified from human fetal and adult tissue. J. Biol. Chem. 247; 1930-1935, 1972.

20. Watson, G. H., Korach, K. S. and Muldoon, T. G.: Obstruction of estrogen-receptor complex formation. Further analysis of the nature and steroidal specificity of the effect. Endocrinology 101; 1733-1743, 1977. 